\title{
An estimate of phytate intake and molar ratio of phytate to zinc in the diet of the people in the United Kingdom
}

\author{
F Amirabdollahian ${ }^{1, *}$ and $\mathrm{R} \mathrm{Ash}{ }^{2}$ \\ 'Department of Physiotherapy and Dietetics, Coventry University, Priory Street, Coventry, CV1 5FB, UK: \\ ${ }^{2}$ Department of Health and Human Sciences, London Metropolitan University, London, UK
}

Submitted 24 August 2009: Accepted 10 February 2010: First published online 22 April 2010

\begin{abstract}
Objective: To estimate the phytate intake and molar ratio of phytate to zinc in the diet of the people in the United Kingdom.

Design: Tables of the phytate content of foods were developed from twenty-eight published and unpublished studies. They were then applied to the nutrient databank of the National Diet and Nutrition Survey (NDNS). The study is a retrospective analysis of data on daily consumption of foods and drinks from the NDNS of children, adolescents, adults and the elderly based on 4-7 d weighed intakes.

Subjects: A total of 6786 British participants aged 1.5 years and above, who participated in the NDNS, 1992-2001.

Setting: England, Scotland and Wales.

Results: The median daily intakes of phytate for children, adolescents, adults and the elderly population were 496, 615, 809 and $629 \mathrm{mg} / \mathrm{d}$, respectively. Although there were differences in phytate intakes between men and women, and for children, adolescents and elderly populations, after adjusting for differences in energy intake, there was no significant variation. The median phytate-to-zinc molar ratios for children, adolescents, adults and the elderly population were 11.8, 10.4, 9.7 and 8.7, respectively. Overall, the main sources of phytate were cereal and cereal products (e.g. breakfast cereals and breads), vegetables, potatoes and savoury snacks (e.g. chips and crisps), hot drinks and miscellaneous foods (e.g. commercial toddler foods and drinks, chocolate and soups), fruits and nuts.

Conclusions: The present study estimated the dietary intake of phytate and the phytate-to-zinc molar ratio of the diet of the UK population, which can be used for estimating the average requirement of zinc. Further research should focus on the completion and validation of the tables of phytate content of UK foods, to assess (and if necessary improve) the accuracy and precision of these findings.
\end{abstract}

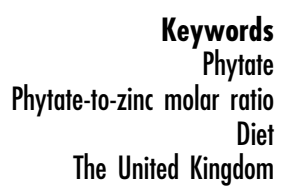

To estimate the average zinc requirement, it is necessary to have an estimate of the physiologic zinc requirement together with an estimate of the proportion of zinc absorbed. The models of zinc absorption ${ }^{(1,2)}$ predict the proportion of zinc absorption from the dietary intake of zinc and phytate. The extent to which phytate affects the absorption of zinc in the UK diet has been difficult to estimate because information on the phytate content of foods consumed in the United Kingdom has not been readily available.

There are many studies on the phytate content of various foods but these studies do not constitute an extensive database on the phytate content of foods. The development of such a database is difficult for several reasons.

First, there is no universally accepted method to assess the phytate content of foods. Large differences were found in direct comparisons of results obtained from a variety of methods; therefore, a large variation in the content of phytate has been reported ${ }^{(2,3)}$. Second, many factors such as growing conditions, maturity, type of soil, variety and mill fraction of grain, genetics, environmental changes, location, irrigation, year and application of fertilisers can affect the phytate content of foods ${ }^{(4,5)}$, adding to the variability in the reported values. Finally, conducting a food survey that includes a representative sampling from all food groups is technically difficult.

In the United Kingdom, there have been very few and inconclusive data on the phytate content of the foods consumed $^{(6-11)}$, and data on the phytate intake of the UK population are scarce. The dietary intake of phytate and its meal distribution pattern were assessed in seventy-six students and staff at the Robert Gordon Institute of Technology ${ }^{(12)}$. Findings of that study cannot be generalised to the UK population because the study was conducted on a very limited number of participants more than 20 years ago. Dietary phytate intake of the UK 
population was also commented on in 1982, although details of the investigation were not published ${ }^{(13)}$.

Thus, the aims of the present study were to: (i) generate a database on the phytate content of foods consumed in the United Kingdom; (ii) apply the database to the data of the National Diet and Nutrition Survey (NDNS) to evaluate the phytate intake of the UK population and to determine the variations associated with gender and age groups; and (iii) evaluate the dietary phytate-to-zinc molar ratio of the population and estimate the representative values for gender and age groups to be used for the calculation of zinc absorption. This will ultimately allow the revision of the Estimated Average Requirement of zinc for the population.

\section{Materials and methods}

\section{Selection of data}

This investigation was a retrospective study among the British population based on the data obtained in the NDNS programme. The four most recent surveys of the NDNS (i.e. children aged $1 \cdot 5-4.5$ years, young people aged 4-18 years, adults aged 19-64 years and people aged 65 years and above) were used. The design and sampling procedure of these surveys are described in the survey reports ${ }^{(14-21)}$.

\section{Phytate content of foods}

Data on the phytate content of different foods are not available in the UK food composition tables ${ }^{(22)}$. Phytate values were therefore derived from published ${ }^{(3-5,7-11,23-35)}$ and unpublished ${ }^{(6,36,37)}$ data. As these values were to be used for analysing NDNS data, the tables were produced to reflect the food types and food groups used for the dietary assessments in the NDNS.

Foods were divided into twelve main food types including (i) cereal and cereal products, (ii) milk and milk products, (iii) eggs and egg dishes, (iv) fat spreads, (v) meat and meat products, (vi) fish and fish dishes, (vii) vegetables, potatoes and savoury snacks, (viii) fruit and nuts, (ix) sugar, preserves and confectionery, (x) total drinks, (xi) miscellaneous and (xii) dietary supplements and artificial sweeteners.

Each of the food types consisted of one or more food groups expressed as integers (e.g. 1=main group of pasta, rice and other miscellaneous cereals). Foods consumed in the United Kingdom were classified into fiftyseven main groups. Food groups were then divided to 115 subsidiary groups that were expressed as integers with an alphabetical suffix (e.g. $1 \mathrm{~A}=$ subsidiary food group of pasta).

A total of 300 foods commonly consumed in the United Kingdom were selected and numbered as examples of foods within the subsidiary food groups. Each of these foods was allocated to one of the 115 subsidiary food groups (e.g. $1 \mathrm{~A} 1=$ noodles, dry form was allocated to subsidiary food group of $1 \mathrm{~A}$; pasta). The phytate content of these foods was then estimated from the published and unpublished data. These values in turn were aggregated into the phytate values for subsidiary food groups.

The phytate content of foods in the literature was usually a mean value from a number of different samples and studies; hence, there was considerable variability associated with most values. In these cases, the range of the values in the literature was mentioned, citing the references. However, the values were aggregated to a single value on the phytate content of the subsidiary food group.

A number of factors were considered when collating phytate content of the various sources. First, the data source and its applicability to UK foods were taken into account, and second, the analytical sample numbers and an analytical method were used. When there was insufficient information for evaluating the suitability of the phytate values, the mean of the values was used after excluding the obvious outliers. If there was doubt regarding specific foods, advice was sought from the researcher of the original investigation. This was the approach used in the development and modification of the meal-based intake assessment tool (MBIAT) software $^{(38)}$ in the Institute of Food Research (Norwich, UK) and endorsed by the experts in the field ${ }^{(36)}$.

Table 1 is an example of estimates of the phytate content of foods for nuts and seeds. A complete table of the phytate content of subsidiary food groups, with examples of the phytate values of the foods included in each subsidiary food group, is available from the authors. Figure 1 illustrates the process used to estimate the phytate content of foods and the phytate intake of the individuals.

\section{Phytate intake of the individuals}

Information on the amount of subsidiary foods consumed over a 4 or $7 \mathrm{~d}$ period is available for the participants who completed food diaries during the NDNS. The phytate values of the subsidiary food groups were added to the nutrient databank of the NDNS and the estimated phytate intake from these groups was then calculated.

Total phytate intake from the main food groups was then calculated by aggregating the phytate intake of the related subgroups. The phytate intake from all foods was then aggregated and divided by the number of days that the food diaries were recorded. This generated the estimated average daily phytate intake of the individuals.

\section{Statistical analysis}

Normal probability plots, $Z_{\text {Skewness }}$ and $Z_{\text {Kurtosis }}$, KolmogorovSmirnov and Shapiro-Wilk tests were used to investigate whether variables followed a normal distribution. The mean, median and quartile ranges were used to express 
Table 1 Estimates of phytate content of nuts and seeds

\begin{tabular}{lcll}
\hline$n$ & Code & \multicolumn{1}{c}{ Food } & Phytate $(\mathrm{mg} / 100 \mathrm{~g})$ \\
\hline 56 & & & \\
& $56 \mathrm{R}$ & Nuts and seeds & 850 \\
223 & Includes fruit and nut mixes, salted peanuts, peanut butter, tahini, Bombay mix \\
224 & $56 \mathrm{R} 1$ & Peanuts (roasted) & $680-2008^{(9,23,28,33)}$ \\
225 & $56 \mathrm{R} 2$ & Peanuts and raisins & $440^{(9)}$ \\
226 & $56 \mathrm{R} 3$ & Peanut butter & $443-1252^{(26,28,36)}$ \\
227 & $56 \mathrm{R} 4$ & Almonds & $970-2111^{(9,24,25,28,33)}$ \\
228 & $56 \mathrm{R} 5$ & Cashews (roasted) & $937-1229^{(9,24,25,28,33)}$ \\
229 & $56 \mathrm{R} 6$ & Macadamia nuts & $290-340^{(9,33)}$ \\
230 & $56 \mathrm{R} 7$ & Walnuts & $580-1977^{(9,24,25,33)}$ \\
231 & $56 \mathrm{R} 8$ & Brazil nuts & $1320-1799^{(9,24,25)}$ \\
232 & $56 \mathrm{R} 9$ & Chestnuts & $10-47^{(9,24,25)}$ \\
233 & $56 \mathrm{R} 10$ & Pistachio nuts & $340^{(9)}$ \\
234 & $56 \mathrm{R} 11$ & Bombay mix & $577^{(36)}$ \\
235 & $56 \mathrm{R} 12$ & Sunflower seeds & $3000^{(9)}$ \\
& $56 \mathrm{R} 13$ & Sesame seeds & $1380^{(9)}$
\end{tabular}

Table shows the phytate content of main and subsidiary food groups in nuts and seeds. Food groups are divided into food types (i.e. fruit and nuts), food groups (i.e. 56: nuts and seeds) and subsidiary food groups (i.e. 56R: nuts and seeds).

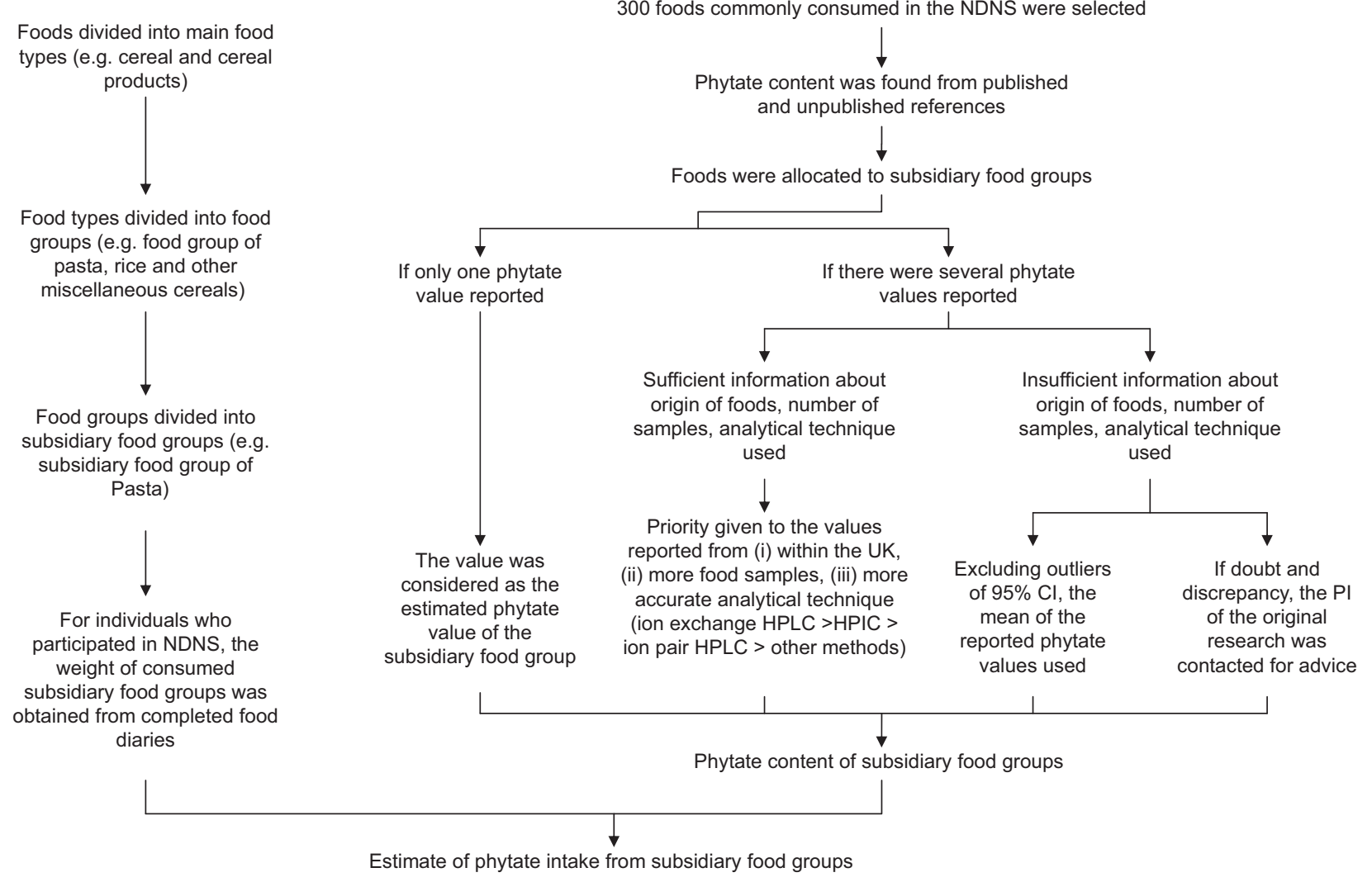

Fig. 1 The process used to estimate phytate intake from the subsidiary food groups (NDNS, National Diet and Nutrition Survey; HPIC, high-performance ion chromatography; PI, principal investigator)

the dietary intake of phytate and the molar ratio of phytate to zinc, as these variables were not normally distributed.

To eliminate any difference owing to energy intake between genders and age groups, the phytate intake was also expressed as density per $4184 \mathrm{~kJ}(1000 \mathrm{kcal})$ energy intake. The phytate-to-zinc molar ratio for the diets of the individuals was calculated as follows ${ }^{(2,39)}$ :

$$
\text { Phytate-to-zinc molar ratio }=\frac{\text { Phytate }(\mathrm{mg}) / 660}{\text { Zinc }(\mathrm{mg}) / 65 \cdot 4}
$$

The non-parametric Mann-Whitney and Kruskal-Wallis (with post hoc comparison based on Benferroni correction) tests were used to compare the differences between 
gender and age groups. For all non-parametric tests, the $P$ value of the Monte Carlo two-tailed exact significance was reported based on the number of samples and a 95\% CI. All statistical analyses were conducted with the Statistical Package for the Social Sciences statistical software package version $14 \cdot 0$ for Windows (SPSS Inc., Chicago, IL, USA).

\section{Results}

\section{Phytate intake in children aged 1.5-4.5 years}

The median daily intake of phytate for boys in the survey was $509 \mathrm{mg}$, and for girls it was significantly lower at $481 \mathrm{mg}(P<0 \cdot 05)$. No variation in phytate intake between boys and girls was found after adjusting for differences in energy intake $(P>0 \cdot 05)$.

The median phytate intake slightly increased with age, being lowest for children aged $1 \cdot 5-2 \cdot 5$ years $(464 \mathrm{mg})$ and highest for children aged $3.5-4.5$ years $(510 \mathrm{mg}, P<0.05)$. Phytate intake decreased with age when differences in energy intake were taken into account, falling from $453.9 \mathrm{mg} / 4184 \mathrm{~kJ}$ (1000 kcal) for the youngest age group to $426.7 \mathrm{mg} / 4184 \mathrm{~kJ}$ (1000 kcal) for the oldest age group $(P<0 \cdot 05)$.

Overall, the median molar ratio of phytate to zinc was $11 \cdot 84$. There were no significant gender and age differences in the phytate-to-zinc molar ratios of children $(P>0.05)$. The mean, median and quartiles of phytate intake, phytate density and molar ratio of phytate to zinc are presented in Table 2 .

In children aged $1.5-4.5$ years, the main sources of phytate were cereal and cereal products (e.g. whole-grain and high-fibre breakfast cereals, biscuits, breads and pasta), miscellaneous foods (e.g. commercial toddler foods and drinks, beverages and soups) and vegetables, potatoes and savoury snacks (e.g. chips, crisps and savoury snacks, baked beans and potato salads and dishes).

\section{Phytate intake in young people aged 4-18 years}

The median daily intake of phytate was $674 \mathrm{mg}$ for boys, whereas in girls this was significantly lower at $566 \mathrm{mg}$
$(P<0 \cdot 001)$. After allowing for variation in the intake of energy, the median intake of phytate per $4184 \mathrm{~kJ}$ $(1000 \mathrm{kcal})$ energy in boys was not significantly different from girls $(365.4 \mathrm{mg} / 4184 \mathrm{~kJ}$ (1000 kcal) $v .362 .5 \mathrm{mg} /$ $4184 \mathrm{~kJ}$ (1000 kcal), $P>0 \cdot 05$ ).

The median daily phytate intake increased with age for boys from $576 \mathrm{mg}$ for participants aged 4-6 years to $780 \mathrm{mg}$ for 15 - to 18 -year-olds $(P<0 \cdot 001)$. For girls, there was a similar increase with age only among girls aged less than 15 years. The median daily phytate intake increased from $494 \mathrm{mg}$ among girls aged $4-6$ years to $574 \mathrm{mg}$ among 11- to 14-year-olds $(P<0 \cdot 001)$.

After allowing for variations in intake of energy, the median intakes of phytate per $4184 \mathrm{~kJ}$ ( $1000 \mathrm{kcal})$ energy for boys and girls were not significantly different among the different age groups $(P>0 \cdot 05)$.

The median molar ratio of phytate to zinc was $10 \cdot 35$. No variation in the phytate-to-zinc molar ratio was observed between boys and girls. The age-related difference in the median values of phytate-to-zinc molar ratio was significant only in boys, with the oldest group of boys having a significantly lower phytate-to-zinc molar ratio compared to those aged $4-6$ years $(P<0 \cdot 001), 7-10$ years $(P<0 \cdot 001)$ and 11-14 years $(P<0 \cdot 01)$.

The mean, median and quartiles of phytate intake, phytate density and phytate-to-zinc molar ratios are presented in Table 3.

More than half of the phytate intake came from the consumption of cereal and cereal products (e.g. wholegrain and high-fibre breakfast cereals, white breads, biscuits, rice and pasta). Over a quarter of phytate intake came from vegetables, potatoes and savoury snacks. A further $9 \%$ of the phytate intake came from miscellaneous food types (mostly beverages such as chocolate, cocoa, etc.) followed by a $5 \%$ contribution from fruit and nuts (mainly from apples and pears followed by nuts and seeds).

\section{Phytate intake in adults aged 19-64 years}

The median daily phytate intake was $886 \mathrm{mg}$ for men, and significantly lower for women $(754 \mathrm{mg}, P<0 \cdot 001)$. In both

Table 2 The mean, median and quartiles of the phytate intake, phytate density and molar ratio of phytate to zinc in children aged $1 \cdot 5-4 \cdot 5$ years

\begin{tabular}{|c|c|c|c|c|c|c|c|c|c|c|c|c|c|}
\hline \multirow[b]{3}{*}{ Gender and age groups } & \multirow[b]{3}{*}{ Base $(n)$} & \multicolumn{4}{|c|}{ Phytate intake (mg/d) } & \multicolumn{4}{|c|}{ Phytate density $(\mathrm{mg} / 1000 \mathrm{kcal})^{*}$} & \multicolumn{4}{|c|}{ Phytate-to-zinc molar ratio } \\
\hline & & \multirow[b]{2}{*}{ Mean } & \multirow[b]{2}{*}{ Median } & \multicolumn{2}{|c|}{ Quartiles } & \multirow[b]{2}{*}{ Mean } & \multirow[b]{2}{*}{ Median } & \multicolumn{2}{|c|}{ Quartiles } & \multirow[b]{2}{*}{ Mean } & \multirow[b]{2}{*}{ Median } & \multicolumn{2}{|c|}{ Quartiles } \\
\hline & & & & P25 & P75 & & & P25 & P75 & & & P25 & P75 \\
\hline Boys aged $1.5-2.5$ years & 298 & 601 & 465 & 353 & 733 & $570 \cdot 4$ & $449 \cdot 2$ & $334 \cdot 0$ & $706 \cdot 2$ & $14 \cdot 13$ & $11 \cdot 50$ & $8 \cdot 08$ & $17 \cdot 37$ \\
\hline Boys aged $2 \cdot 5-3.5$ years & 300 & 636 & 515 & 408 & 718 & $536 \cdot 9$ & $+3 \cdot 4$ & $337 \cdot 2$ & $591 \cdot 1$ & $14 \cdot 77$ & $12 \cdot 41$ & $9 \cdot 47$ & $16 \cdot 92$ \\
\hline Boys aged $3.5-4.5$ years & 250 & 605 & 526 & 406 & 725 & $474 \cdot 4$ & $428 \cdot 8$ & $323 \cdot 4$ & $550 \cdot 3$ & $13 \cdot 36$ & $11 \cdot 84$ & $9 \cdot 03$ & $15 \cdot 83$ \\
\hline All boys & 848 & 615 & 509 & 379 & 724 & $530 \cdot 2$ & $440 \cdot 2$ & $333 \cdot 0$ & $595 \cdot 9$ & $14 \cdot 13$ & 11.94 & $8 \cdot 92$ & $16 \cdot 92$ \\
\hline Girls aged $1.5-2.5$ years & 278 & 615 & 463 & 332 & 695 & $616 \cdot 5$ & $461 \cdot 7$ & $313 \cdot 5$ & $690 \cdot 3$ & $15 \cdot 39$ & $11 \cdot 90$ & $8 \cdot 10$ & $17 \cdot 18$ \\
\hline Girls aged $2 \cdot 5-3.5$ years & 306 & 577 & 483 & 337 & 688 & $510 \cdot 0$ & $429 \cdot 3$ & $332 \cdot 9$ & $614 \cdot 0$ & $13 \cdot 74$ & 11.90 & $8 \cdot 94$ & $15 \cdot 78$ \\
\hline Girls aged $3 \cdot 5-4.5$ years & 243 & 566 & 497 & 379 & 680 & $486 \cdot 8$ & $426 \cdot 7$ & $328 \cdot 7$ & $603 \cdot 4$ & $13 \cdot 25$ & $11 \cdot 58$ & $9 \cdot 10$ & $16 \cdot 27$ \\
\hline All girls & 827 & 587 & 481 & 347 & 687 & $539 \cdot 0$ & $435 \cdot 5$ & $329 \cdot 5$ & $626 \cdot 0$ & $14 \cdot 15$ & $11 \cdot 78$ & $8 \cdot 76$ & $16 \cdot 40$ \\
\hline All boys and girls & 1675 & 601 & 496 & 368 & 707 & $534 \cdot 6$ & $439 \cdot 1$ & 331.5 & $616 \cdot 5$ & $14 \cdot 14$ & $11 \cdot 84$ & $8 \cdot 85$ & $16 \cdot 56$ \\
\hline
\end{tabular}

\footnotetext{
${ }^{*} 1 \mathrm{kcal}=4 \cdot 184 \mathrm{~kJ}$.
} 
men and women, the youngest age groups had significantly lower phytate intake compared with older age groups. This difference was associated with different energy intake between the age groups; however, even after adjustment for variation in energy intake, the youngest groups in both genders still had a significantly lower intake of phytate per $4184 \mathrm{~kJ}(1000 \mathrm{kcal})$ energy $(P<0 \cdot 001)$.

The median molar ratio of phytate to zinc was 8.82 for men, and significantly higher for women at $10 \cdot 28$ $(P<0 \cdot 01)$. For men, there were no significant differences by age in the phytate-to-zinc molar ratios.

Women in the youngest age group had a significantly lower phytate-to-zinc molar ratio than women in any other age group (35-49 years: $P<0 \cdot 05$, all others $P<0 \cdot 01$ ). The mean, median and quartiles of the phytate intake, phytate density and phytate-to-zinc molar ratios are presented in Table 4.

The main source of phytate for the respondents of the survey was from cereal and cereal products, contributing approximately half of the average phytate intake. Vegetables, potatoes and savoury snacks contributed more than quarter of the average daily phytate intake. Within this group, the main contributors were potatoes, potato salads and dishes, baked beans, vegetables (not raw) and chips. Total drinks (including coffee, tea and fruit juice), miscellaneous foods (including beverages and soups) and fruits and nuts provided a further $8 \%, 7 \%$ and $6 \%$ of average daily phytate intake, respectively.

Phytate intake in people aged 65 years and above

The median daily intake of phytate for men was $727 \mathrm{mg}$, and for women it was significantly lower at $572 \mathrm{mg}$ $(P<0 \cdot 001)$. This gender difference was largely associated with the difference in energy intake between the genders, as adjusting for this variation resulted in no significant difference in phytate intake per $4184 \mathrm{~kJ}$ ( $1000 \mathrm{kcal})$ energy intake. No variation in phytate intake and density was found between the different age groups of men and women.

The median molar ratio of phytate to zinc was $8 \cdot 70$. There were no significant differences in the phytate-tozinc molar ratios between men and women or among different age groups. The mean, median and quartiles of the phytate intake, phytate density and phytate-to-zinc molar ratios are presented in Table 5 .

The average intake of phytate $(60 \%)$ came from the consumption of cereal and cereal products. Breakfast cereals, breads, biscuits and buns, cakes and pastries were the main contributors within this group.

Vegetables, potatoes and savoury snacks (mainly potatoes, potato salads and dishes, chips, boiled vegetables and baked beans) contributed $23 \%$ of the average daily phytate intake. Fruit and nuts contributed a further $5 \%$ to the average daily intake of phytate (mainly apples and pears, followed by other fruits including plums, grapes and apricots, which were either raw, stewed, dried or in the form of fruit salads). Table 6 shows 
Table 4 The mean, median and quartiles of the phytate intake, phytate density and molar ratio of phytate to zinc in adults aged 19-64 years

\begin{tabular}{|c|c|c|c|c|c|c|c|c|c|c|c|c|c|}
\hline \multirow[b]{3}{*}{ Gender and age groups } & \multirow[b]{3}{*}{ Base $(n)$} & \multicolumn{4}{|c|}{ Phytate intake (mg/d) } & \multicolumn{4}{|c|}{ Phytate density $(\mathrm{mg} / 1000 \mathrm{kcal})^{\star}$} & \multicolumn{4}{|c|}{ Phytate-to-zinc molar ratio } \\
\hline & & \multirow[b]{2}{*}{ Mean } & \multirow[b]{2}{*}{ Median } & \multicolumn{2}{|c|}{ Quartiles } & \multirow[b]{2}{*}{ Mean } & \multirow[b]{2}{*}{ Median } & \multicolumn{2}{|c|}{ Quartiles } & \multirow[b]{2}{*}{ Mean } & \multirow[b]{2}{*}{ Median } & \multicolumn{2}{|c|}{ Quartiles } \\
\hline & & & & P25 & P75 & & & P25 & P75 & & & P25 & P75 \\
\hline Males aged $19-24$ years & 108 & 817 & 762 & 565 & 940 & $404 \cdot 7$ & $365 \cdot 7$ & $303 \cdot 0$ & $421 \cdot 7$ & $9 \cdot 23$ & $8 \cdot 21$ & $6 \cdot 82$ & $10 \cdot 30$ \\
\hline Males aged $25-34$ years & 219 & 1010 & 904 & 659 & 1132 & 474.9 & $432 \cdot 8$ & $357 \cdot 5$ & $527 \cdot 9$ & $9 \cdot 76$ & $9 \cdot 11$ & $7 \cdot 31$ & $11 \cdot 47$ \\
\hline Males aged $35-49$ years & 253 & 993 & 903 & 670 & 1262 & $465 \cdot 1$ & $430 \cdot 5$ & $326 \cdot 8$ & $555 \cdot 5$ & $9 \cdot 57$ & $8 \cdot 80$ & $6 \cdot 58$ & $11 \cdot 65$ \\
\hline Males aged $50-64$ years & 253 & 1094 & 948 & 679 & 1314 & $522 \cdot 5$ & $449 \cdot 7$ & $357 \cdot 7$ & $607 \cdot 3$ & $10 \cdot 48$ & $9 \cdot 27$ & $7 \cdot 24$ & $12 \cdot 23$ \\
\hline All males & 833 & 1005 & 886 & 657 & 1178 & $477 \cdot 2$ & $419 \cdot 1$ & $335 \cdot 7$ & $545 \cdot 5$ & $9 \cdot 85$ & $8 \cdot 82$ & $7 \cdot 02$ & $11 \cdot 43$ \\
\hline Females aged $19-24$ years & 104 & 650 & 645 & 438 & 790 & $420 \cdot 5$ & 398.9 & $320 \cdot 6$ & $502 \cdot 2$ & $9 \cdot 70$ & $9 \cdot 28$ & $7 \cdot 00$ & $12 \cdot 11$ \\
\hline Females aged $25-34$ years & 210 & 756 & 714 & 486 & 910 & $510 \cdot 2$ & $473 \cdot 9$ & $370 \cdot 7$ & $589 \cdot 0$ & $11 \cdot 17$ & $10 \cdot 50$ & $8 \cdot 20$ & $13 \cdot 23$ \\
\hline Females aged $35-49$ years & 318 & 868 & 792 & 568 & 1071 & $556 \cdot 8$ & $505 \cdot 4$ & $382 \cdot 7$ & $668 \cdot 6$ & $11 \cdot 63$ & $10 \cdot 27$ & $8 \cdot 00$ & $14 \cdot 03$ \\
\hline Females aged $50-64$ years & 259 & 928 & 807 & 599 & 1138 & $605 \cdot 9$ & $522 \cdot 9$ & $401 \cdot 5$ & $706 \cdot 7$ & $11 \cdot 86$ & $10 \cdot 51$ & $8 \cdot 26$ & $13 \cdot 82$ \\
\hline All females & 891 & 834 & 754 & 546 & 1013 & $544 \cdot 1$ & $482 \cdot 0$ & $371 \cdot 5$ & $652 \cdot 2$ & $11 \cdot 36$ & $10 \cdot 28$ & $7 \cdot 97$ & $13 \cdot 59$ \\
\hline All males and females & 1724 & 917 & 809 & 595 & 1100 & $511 \cdot 8$ & $452 \cdot 0$ & $353 \cdot 6$ & $601 \cdot 3$ & $10 \cdot 63$ & $9 \cdot 66$ & $7 \cdot 47$ & $12 \cdot 55$ \\
\hline
\end{tabular}

${ }^{*} 1 \mathrm{kcal}=4 \cdot 184 \mathrm{~kJ}$.

Table 5 The mean, median and quartiles of the phytate intake, phytate density and molar ratio of phytate to zinc in adults aged 65 years and above

\begin{tabular}{|c|c|c|c|c|c|c|c|c|c|c|c|c|c|}
\hline \multirow[b]{3}{*}{ Gender and age groups } & \multirow[b]{3}{*}{ Base $(n)$} & \multicolumn{4}{|c|}{ Phytate intake (mg/d) } & \multicolumn{4}{|c|}{ Phytate density $(\mathrm{mg} / 1000 \mathrm{kcal})^{*}$} & \multicolumn{4}{|c|}{ Phytate-to-zinc molar ratio } \\
\hline & & \multirow[b]{2}{*}{ Mean } & \multirow[b]{2}{*}{ Median } & \multicolumn{2}{|c|}{ Quartiles } & \multirow[b]{2}{*}{ Mean } & \multirow[b]{2}{*}{ Median } & \multicolumn{2}{|c|}{ Quartiles } & \multirow[b]{2}{*}{ Mean } & \multirow[b]{2}{*}{ Median } & \multicolumn{2}{|c|}{ Quartiles } \\
\hline & & & & P25 & P75 & & & P25 & P75 & & & P25 & P75 \\
\hline Males aged $65-74$ years & 371 & 891 & 733 & 509 & 1112 & $455 \cdot 4$ & $386 \cdot 0$ & $267 \cdot 7$ & $549 \cdot 2$ & $9 \cdot 69$ & $8 \cdot 70$ & $6 \cdot 26$ & $11 \cdot 50$ \\
\hline Males aged $75-84$ years & 200 & 938 & 692 & 453 & 1145 & $504 \cdot 4$ & $378 \cdot 5$ & $264 \cdot 5$ & $582 \cdot 3$ & $10 \cdot 96$ & $8 \cdot 78$ & $6 \cdot 32$ & $12 \cdot 58$ \\
\hline Males aged 85 years and above & 62 & 1059 & 779 & 496 & 1419 & $569 \cdot 1$ & $411 \cdot 4$ & $286 \cdot 8$ & $827 \cdot 5$ & $12 \cdot 67$ & $8 \cdot 97$ & $7 \cdot 13$ & $17 \cdot 94$ \\
\hline All males & 633 & 923 & 727 & 495 & 1131 & $482 \cdot 1$ & $386 \cdot 0$ & $267 \cdot 9$ & $571 \cdot 3$ & $10 \cdot 38$ & $8 \cdot 72$ & $6 \cdot 35$ & $12 \cdot 08$ \\
\hline Females aged $65-74$ years & 434 & 693 & 630 & 426 & 849 & $476 \cdot 8$ & $434 \cdot 9$ & $310 \cdot 5$ & $570 \cdot 4$ & $9 \cdot 70$ & $8 \cdot 93$ & $6 \cdot 43$ & $11 \cdot 26$ \\
\hline Females aged $75-84$ years & 368 & 674 & 549 & 392 & 777 & $466 \cdot 3$ & $368 \cdot 8$ & $284 \cdot 7$ & $574 \cdot 4$ & $9 \cdot 72$ & $8 \cdot 50$ & $6 \cdot 25$ & $10 \cdot 91$ \\
\hline Females aged 85 years and above & 251 & 712 & 538 & 416 & 772 & $467 \cdot 2$ & $336 \cdot 8$ & $271 \cdot 4$ & $518 \cdot 5$ & $10 \cdot 62$ & $8 \cdot 40$ & $6 \cdot 90$ & $11 \cdot 62$ \\
\hline All females & 1054 & 690 & 572 & 416 & 813 & $470 \cdot 8$ & $387 \cdot 8$ & $285 \cdot 6$ & $556 \cdot 4$ & $9 \cdot 93$ & $8 \cdot 65$ & $6 \cdot 48$ & $11 \cdot 07$ \\
\hline All males and females & 1687 & 778 & 629 & 434 & 915 & $475 \cdot 1$ & $386 \cdot 9$ & $277 \cdot 6$ & $557 \cdot 8$ & $10 \cdot 10$ & $8 \cdot 70$ & $6 \cdot 42$ & $11 \cdot 44$ \\
\hline
\end{tabular}

${ }^{*} 1 \mathrm{kcal}=4 \cdot 184 \mathrm{~kJ}$.

Table 6 Percentage contribution of food types to average daily phytate intake of children aged $1.5-4.5$ years, young people aged 4-18 years, adults aged 19-64 years and adults aged 65 years and above

\begin{tabular}{|c|c|c|c|c|}
\hline & $\begin{array}{l}\text { Children aged } \\
1.5-4.5 \text { years }\end{array}$ & $\begin{array}{l}\text { Young people aged } \\
4-18 \text { years }\end{array}$ & $\begin{array}{l}\text { Adults aged } \\
19-64 \text { years }\end{array}$ & $\begin{array}{c}\text { Adults aged } 65 \text { years } \\
\text { and above }\end{array}$ \\
\hline Food types & $\%$ & $\%$ & $\%$ & $\%$ \\
\hline Cereal and cereal products & 45 & 52 & 49 & 60 \\
\hline Vegetables, potatoes and savoury snacks & 20 & 27 & 26 & 23 \\
\hline Meat and meat products & 1 & 1 & 2 & 1 \\
\hline Egg and egg dishes & 1 & 0 & 0 & 0 \\
\hline Fruits and nuts & 4 & 5 & 6 & 5 \\
\hline Sugar, preserves and confectionary & 4 & 4 & 2 & 1 \\
\hline Total drinks & 0 & 2 & 8 & 5 \\
\hline Miscellaneous & 25 & 9 & 7 & 5 \\
\hline
\end{tabular}

the contribution of food types (by percentage) to the average daily phytate intake of the UK population.

\section{Discussion}

\section{Tables of phytate content and their limitations}

The tables on the phytate content of foods were extrapolated from published and unpublished data. Inaccuracies could have arisen in the estimation of the phytate content of foods for a number of reasons. First, there is variation in the phytate content of varieties, genotypes and species of foods ${ }^{(40-43)}$. For example, the phytate content of Korean foods ${ }^{(23)}$ used in the generation of tables of phytate content of subsidiary food groups may be different from the phytate content of UK foods. Data extracted from book chapters (e.g. Harland ${ }^{(24)}$ ) are also used for generation of the phytate table; however, they are not necessarily derived from 
peer-reviewed sources. Second, estimates of the phytate contents of foods are dependent on the assays used, sampling procedures and environmental factors. Hence, the accuracy of the estimates will depend on the accuracy of the analyses ${ }^{(44,45)}$. Finally, for many foods, phytate values have not been measured or were not found in the literature; in which case, the reported value has been estimated from the phytate values of foods of similar composition $^{(38)}$.

The authors acknowledge that these tables might be prone to errors, but these inaccuracies were considered as the limitations of the study and were due to the difficulties associated with the assessment of nutrient intake using food composition tables ${ }^{(45)}$.

Steps were taken to minimise the impact of error. The primary references used ${ }^{(24,25,35,36)}$ were those that had been validated, updated and often cited in the literature on the phytate content of foods. Considerable variability in the mean and range of the values quoted in the literature was taken into account and values deemed to be outliers were excluded.

Estimates of the phytate content were compared against the nutrient database of MBIAT software, developed by the Institute of Food Research ${ }^{(38)}$. The final version of the tables were sent to the authors of MBIAT for review $^{(46,47)}$.

Opportunities to set geographic criteria or to select the investigations that used the same analytical technique were very limited. Results from studies using the anion exchange HPLC, which is a well-established method for the assessment of phytate content of food, were selected above those obtained from other techniques. However, for at least five studies, the authors had to include investigations based on methods other than anion exchange HPLC ${ }^{(5,6,29,30,33)}$ to extend the range of data.

\section{Comparison with otber investigations}

The average phytate intake of adults in the United Kingdom is higher than that in developed countries (e.g. Finland, $370 \mathrm{mg} / \mathrm{d}^{(48)}$ and the United States, $\left.750 \mathrm{mg} / \mathrm{d}^{(49)}\right)$ and lower than in African and Asian countries (e.g. Nigeria, $2200 \mathrm{mg} / \mathrm{d}^{(50)}$; India, $1955 \mathrm{mg} / \mathrm{d}^{(51)}$; and South Korea, $\left.1677 \mathrm{mg} / \mathrm{d}^{(52)}\right)$. The median daily phytate intake of adults in the United Kingdom ( $809 \mathrm{mg} / \mathrm{d}$ ) is comparable to the median phytate intake in urban China $(781 \mathrm{mg} / \mathrm{d})$ and lower than in rural China $(1342 \mathrm{mg} / \mathrm{d})^{(53)}$.

Comparing these findings to other studies in the United Kingdom is difficult. The average phytate intake of adults is close to the values suggested by Davies ${ }^{(13)}$ in 1982. Davies concluded that the phytate intake of the UK population is in the range of $600-800 \mathrm{mg} / \mathrm{d}$, although details of the investigation were unpublished.

Davies also referred to a personal communication with DH Buss (unpublished results) regarding the phytate content of some representative UK diets, which indicated an average daily phytate consumption of $806 \mathrm{mg} / \mathrm{d}$.
In this latter investigation, $70 \%$ of the phytate intake came from cereal products, $20 \%$ from fruit and the remainder from vegetables and nuts. Despite differing definitions for subsidiary food groups in the current investigation, findings from Buss agree with the average phytate intake and the percentage contribution of food types to average daily phytate intake found in the present study.

Findings of the current investigation did not agree with the range of phytate intake reported by Wise et al. ${ }^{(12)}$ in 1987, in which they indicated that the mean phytatephosphorus intake of students and staff at the Robert Gordon Institute of Technology ranged from 141 to $237 \mathrm{mg} / \mathrm{d}$. It is important to note that these results were based on a different methodology and analytical technique (i.e. measurement of phytate-phosphorus), and the study was conducted on a limited number of participants.

The inconsistency between the results presented here and those of Wise et $a l^{(12)}$ may be related to the molecular species of phytate. The low values obtained by Wise et al. may represent a decreased phosphorylation state of phytate (e.g. IP2 or IP3) and thus lower zinc chelation potency. This is possible particularly since the majority of phytate intake in the study of Wise et $a l^{(12)}$ also came from breakfast cereals and breads, which agrees with findings of the current investigation. The foods may have been processed by extrusion (i.e. subjected to heat) and breads (subjected to phytase activity during fermentation). The lack of information on the phosphorylation state of phytate is another limitation of the current analysis.

\section{Types of foods contributing to phytate intake}

Cereal and cereal products were the main sources of phytate for the UK population. For all age groups, the majority of phytate intake from cereals came from breakfast cereals and breads. Phytate intake from these foods is high, as (i) they contain a high amount of phytate (e.g. $750 \mathrm{mg}$ phytate in $100 \mathrm{~g}$ high-fibre and whole-grain breakfast cereals) and (ii) they are frequently consumed in the UK diet. The majority of children in the present survey consumed some form of bread and breakfast cereals.

Vegetables, potatoes and savoury snacks were the second largest source of phytate for the UK population. Within this group, the phytate content of the subsidiary food groups is not exclusively high, but the frequency and quantity of consumption have resulted in high phytate intake from these foods. For example, potato chips contain $147 \mathrm{mg}$ phytate per $100 \mathrm{~g}$ chips, and the largest proportion of young people aged 4-18 years (89\% of boys and $88 \%$ of girls) consumed potato chips during the dietary record period. The majority of the young people population also consumed savoury snacks ${ }^{(15)}$.

Lower phytate intake of men and women aged 19-24 years could be explained by general differences in foods consumed by respondents of this group compared with older adults. The foods that were less likely to have been 
consumed by the youngest group of men and women were the rich sources of phytate. For example, men and women aged 19-24 years were less likely to consume wholemeal breads, high-fibre and whole-grain breakfast cereals and coffee. Furthermore, for nearly half of the fruit and vegetable types (i.e. peas, leafy green vegetables, cooked tomatoes, apples, pears, citrus fruits, bananas, canned fruits in juice, and 'other fruit' such as plums, grapes and soft fruits), a significantly lower proportion of men and women aged 19-24 years had consumed these items compared with the oldest age group ${ }^{(16)}$.

In the elderly population, boiled, mashed and baked potatoes, tea, white breads and biscuits were consumed by the largest proportion of the population. Almost all participants (95\% of free-living and $98 \%$ of institution participants) drank tea. The average consumption of twenty-four to twenty-five cups of tea per week was greater than the four to seven cups of coffees per week consumed by the elderly participants ${ }^{(21)}$. This frequent consumption of tea and coffee contributed to a large proportion of phytate intake of adults (aged 19-64 years), as well as the elderly population.

In conclusion, the present study collected the available data on the phytate content of foods, generated a database and produced an estimate of dietary phytate intake and phytate-to-zinc molar ratio for the UK population. Further research should focus on the completion and validation of this database to assess (and if necessary improve) the accuracy and precision of these findings.

\section{Acknowledgements}

The present study received no specific grant from any funding agency in the public, commercial or not-for-profit sectors. The authors have no conflict of interest. As part of a PhD research, F.A. was responsible for study design, conducting the project, data analysis and writing the manuscript. R.A. was responsible for supervising the project and reviewing the first draft. The authors thank the Food Standards Agency, the Ministry of Agriculture, Fisheries and Food, the Department of Health and The Data Archive, University of Essex as related responsible organisations for conducting the National Diet and Nutrition Survey and permitting access to the data. They also thank the iPED Writing Retreat Fellowship sponsored by Coventry University for facilitating the dissemination of the present study.

\section{References}

1. Miller LV, Krebs NF \& Hambidge KM (2007) A mathematical model of zinc absorption in humans as a function of dietary zinc and phytate. J Nutr 137, 135-141.

2. Brown KH, Rivera JA, Bhutta Z et al. (2004) International Zinc Nutrition Consultative Group (IZiNCG) technical document \#1. Assessment of the risk of zinc deficiency in populations and options for its control. Food Nutr Bull 25, Suppl. 2, S99-S203.
3. Brooks SPJ \& Lampi BJ (2001) Problems associated with measuring phytate in infant cereals. J Agric Food Chem 49 , 564-569.

4. Dost K \& Tokul O (2006) Determination of phytic acid in wheat and wheat products by reverse phase high performance liquid chromatography. Anal Chim Acta 558, 22-27.

5. Lehrfeld J (1989) High-performance liquid chromatography analysis of phytic acid on a pH-stable, macroporous polymer column. Cereal Chem 66, 510-515.

6. Brian K \& Lawrance P (1999) Nutrient Analysis of Bread and Morning Goods; Analytical Report, MAFF/DH JFSSG Project Number: AN 1062 (Ref CSA 4768). Unpublished Government Report no. LGC/FA50/99/51.

7. Holland B, Unwin ID \& Buss DH (1988) Cereals and Cereal Products: The Third Supplement to McCance and Widdowson's The Composition of Foods, 4th ed. Cambridge: Royal Society of Chemistry.

8. Holland B, Unwin ID \& Buss DH (1991) Vegetables, Herbs and Spices: The Fifth Supplement to McCance and Widdowson's The Composition of Foods, 4th ed. Cambridge: Royal Society of Chemistry.

9. Holland B, Unwin ID \& Buss DH (1992) Fruit and Nuts: The First Supplement to The Fifth Edition of McCance and Widdowson's The Composition of Foods, 5th ed. Cambridge: Royal Society of Chemistry.

10. Holland B, Welch A, Buss DH et al. (1992) Vegetable Dishes: The Second Supplement to the Fifth Edition of McCance and Widdowson's The Composition of Foods, 5th ed. Cambridge: Royal Society of Chemistry and Ministry of Agriculture, Fisheries and Food.

11. Davies NT \& Warrington S (1986) The phytic acid mineral, trace element, protein and moisture content of UK Asian immigrant foods. Hum Nutr Appl Nutr 40, 49-59.

12. Wise A, Lockie GM \& Liddell J (1987) Dietary intakes of phytate and its meal distribution pattern amongst staff and students in an institution of higher education. BrJ Nutr $\mathbf{5 8}$, 337-346.

13. Davies NT (1982) Effects of phytic acid on mineral availability. In Dietary Fiber in Health and Disease, pp. 105-116 [GV Vahoung and K Kritchevsky, editors]. New York: Plenum Press.

14. Gregory JR, Collins DL, Davies PSW et al. (1995) National Diet and Nutrition Survey: Children Aged 1 1/2 to 4 1/2 Years. vol. 1: Report of the Diet and Nutrition Survey. London: HMSO.

15. Gregory J, Lowe S, Bates CJ et al. (2000) National Diet and Nutrition Survey: Young People Aged 4 to 18 Years. vol. 1: Report of the Diet and Nutrition Survey. London: The Stationery Office.

16. Henderson L, Gregory J \& Swan G (2002) The National Diet and Nutrition Survey: Adults Aged 19 to 64 Years. vol. 1: Types and Quantities of Foods Consumed. London: TSO.

17. Henderson L, Gregory J, Irving K et al. (2003) The National Diet and Nutrition Survey: Adults Aged 19 to 64 Years. vol 2: Energy, Protein, Carbohydrate, Fat and Alcohol Intake. London: TSO.

18. Henderson L, Irving K, Gregory J et al. (2003) The national Diet and Nutrition Survey: Adults Aged 19 to 64 Years. vol. 3: Vitamin and Mineral Intake and Urinary Analytes. London: TSO.

19. Ruston D, Hoare J, Henderson L et al. (2004) The National Diet and Nutrition Survey: Adults Aged 19 to 64 Years. vol. 4: Nutritional Status (Anthropometry and Blood Analytes), Blood Pressure and Physical Activity. London: TSO.

20. Hoare J, Henderson L, Bates CJ et al. (2004) The National Diet and Nutrition Survey: Adults Aged 19 to 64 Years. vol. 5: Summary Report. London: TSO.

21. Finch S, Doyle W, Lowe C et al. (1998) National Diet and Nutrition Survey: People Aged 65 Years and Over. 
vol. 1: Report of the Diet and Nutrition Survey: The Stationary Office.

22. Food Standards Agency (2002) McCance and Widdowson's The Composition of Foods, 6th summary ed. Cambridge: Royal Society of Chemistry.

23. Joung H, Nam G, Yoon S et al. (2004) Bioavailable zinc intake of Korean adults in relation to the phytate content of Korean foods. J Food Compost Anal 17, 713-724.

24. Harland BF (2001) Table A.7. In CRC Handbook of Dietary Fiber in Human Nutrition, 3rd ed., pp. 659-666 [GA Spiller, editor]. Boca Raton, FL: CRC Press.

25. Harland BF \& Oberleas D (1987) Phytate in foods. World Rev Nutr Diet 52, 235-259.

26. Oberleas D \& Harland BF (1981) Phytate content of foods: effect on dietary zinc bioavailability. J Am Diet Assoc 79, 433-436.

27. Vinh LT \& Dworschák E (1985) Phytate content of some foods from plant origin from Vietnam and Hungary. Nabrung 29, 161-166.

28. Harland BF, Smikle-Williams S \& Oberleas D (2004) High performance liquid chromatography analysis of phytate (IP6) in selected foods. J Food Compost Anal 17, 227-233.

29. Lehrfeld J (1994) HPLC separation and quantitation of phytic acid and some inositol phosphates in foods: problems and solutions. J Agric Food Chem 42, 2726-2731.

30. Talamond P, Gallon G, Guyot JP et al. (1998) Comparison of high-performance ion chromatography and absorptiometric methods for the determination of phytic acid in food samples. Analysis 26, 396-400.

31. Davies NT \& Reid H (1979) Evaluation of the phytate, zinc, copper, iron and manganese contents of, and $\mathrm{Zn}$ availability from, soya-based textured vegetable-protein meat-substitutes or meat-extenders. Br J Nutr 41, 579-589.

32. Nitithan S, Komindr S \& Nichachotsalid A (2004) Phytate and fiber content in Thai fruits commonly consumed by diabetic patients. J Med Assoc Thai 87, 1444-1446.

33. Chen QC (2004) Determination of phytic acid and inositol pentakisphosphates in foods by high-performance ion chromatography. J Agric Food Chem 52, 4604-4613.

34. Lind T, Lönnerdal B, Persson LA et al. (2003) Effects of weaning cereals with different phytate contents on hemoglobin, iron stores, and serum zinc: a randomized intervention in infants from 6 to 12 mo of age. Am J Clin Nutr 78, 168-175.

35. Bunch S \& Murphy S (1996) World food dietary assessment system. Version 2.0. http://www.fao.org/infoods/software_ worldfood_en.stm (accessed January 2008).

36. Roe M (2008) Personal Communication, Email; Re: Phytate content of foods in MBIAT. Norwich: (Unpublished); 14 January.

37. Lind T (2008) Personal Communication, Email; Re: Phytate content of milk based cereal drinks. Umea: (Unpublished); 17 January.
38. Heath ALM, Roe MA, Oyston SL et al. (2005) Meal-based intake assessment tool: relative validity when determining dietary intake of $\mathrm{Fe}$ and $\mathrm{Zn}$ and selected absorption modifiers in UK men. BrJ Nutr 93, 403-416.

39. Oberleas D \& Harland BF (2005) Diagnosis of zinc deficiency in population studies. Trace Elem Electrolytes 22, 282-287.

40. Dai F, Wang JM, Zhang SH et al. (2007) Genotypic and environmental variation in phytic acid content and its relation to protein content and malt quality in barley. Food Chem 105, 606-611.

41. Kumar V, Rani A, Rajpal S et al. (2005) Phytic acid in Indian soybean: genotypic variability and influence of growing location. J Sci Food Agric 85, 1523-1526.

42. Chitra U, Vimala V, Singh U et al. (1995) Variability in phytic acid content and protein digestibility of grain legumes. Plant Foods Hum Nutr 47, 163-172.

43. Liu ZH, Wang HY, Wang XE et al. (2006) Genotypic and spike positional difference in grain phytase activity, phytate, inorganic phosphorus, iron, and zinc contents in wheat (Triticum aestivum L.). J Cereal Sci 44, 212-219.

44. Merchant AT \& Dehghan M (2006) Food composition database development for between country comparisons. Nutr J 5, 2.

45. West CE \& van Staveren WA (1997) Food consumption, nutrient intake, and the use of food composition tables. In Design Concepts in Nutritional Epidemiology, 2nd ed., pp. 107-122 [BM Margetts and M Nelson, editors]. New York: Oxford University Press Inc.

46. Heath ALM (2008) Personal Communication, Email; Re: Phytate content of foods in MBIAT. Dunedin: (Unpublished); 14 January.

47. Roe M (2008) Personal Communication, Email; Re: Phytate content of foods in MBIAT. Norwich: (Unpublished); 1 February 2008.

48. Plaami S \& Kumpulainen J (1995) Inositol phosphate content of some cereal-based foods. J Food Compost Anal $\mathbf{8}, 324-335$.

49. Harland BF \& Peterson M (1978) Nutritional-status of lactoovo vegetarian Trappist monks. J Am Diet Assoc 72, 259-264.

50. Harland BF, Oke OL \& Felix-Phipps R (1988) Preliminary studies on the phytate content of Nigerian foods. $J$ Food Compost Anal 1, 202-205.

51. Khokhar S, Pushpanjali \& Fenwick GR (1994) Phytate content of Indian foods and intakes by vegetarian Indians of Hisar Region, Haryana State. J Agric Food Chem 42, 2440-2444.

52. Kwun IS \& Kwon CS (2000) Dietary molar ratios of phytate:zinc and millimolar ratios of phytate $\times$ calcium: zinc in South Koreans. Biol Trace Elem Res 75, 29-41.

53. Ma G, Li Y, Jin Y et al. (2007) Phytate intake and molar ratios of phytate to zinc, iron and calcium in the diets of people in China. Eur J Clin Nutr 61, 368-374. 